\title{
Masonry strain in the Vall d'Aràn churches
}

\author{
J. Lluis i Ginovart, S. Coll-Pla \& M. Lopez-Piquer \\ Escola Tècnica Superior d'Arquitectura (ETSA), \\ Universistat Rovira i Virgili (URV), Spain
}

\begin{abstract}
Located in the north face of the Spanish Pyrenees, it is in the Vall d'Aràn where we find an important ensemble of Romanesque churches built between the 12th and the 16th century. Today those buildings suffer deformations of over $10 \%$ from their original shape.

Puig i Cadafalch (1908) pointed out that, initially, the basilica roof had a wooden truss that transmitted the weight vertically. Years later, these were substituted by barrel vaults, supported on non-monolithic circular section masonry columns, which meant deformations on the buildings.

The level of deformation depends on the stereotomy of the pieces and on the vaults building system. This article is about the different constructive systems used in the churches and the quantification of the geometric deformation in relation with them.

After having done the constructive sections of the lay outs of the Santa Maria d'Unha (12th century), Santa Maria de Arties (12-13th century), Santa Maria de Bossost (13th century) and Sant Andreu de Salardú (14th century) churches (between the years 2011 and 2014), the next step has been to study the deformation. These buildings allow us to study the constructive evolution in a period of four centuries.
\end{abstract}

Keywords: Romanesque, Vall d'Aràn, strain vault.

\section{Introduction}

In the Pyrenees region of Val d'Aran, there is a set of Romanesque churches built between the 12th and 16th centuries (most of them between the 12th and the 13th), with some particular features which distinguish them from other contemporary buildings. The constructive typology presents the typical 
configuration with a central and two lateral naves, covered with a barrel vault and half-vaults respectively.

What distinguish these buildings are the large deformations of the masonry and the buttressing strategies built through centuries to hold them. They have attracted the attention of many architects and historians of construction in Spain through the years. Josep Puig i Cadafalch (1867-1956) [1] made a hypothesis about the covering of these churches. According to his theory, they were covered with a timber structure, and changed for the construction of barrel vaults supported by non-monolithic columns and arches.

From another point of view, Joan Bassegoda i Nonell (1930-2012) [2] stated that the formal anomalies are a feature of the Romanesque architecture produced in Catalunya. Thus, specific peculiarities are set in a characteristic geographic environment; that is the reason of the importance of the early churches in Val d'Aran. One of the most relevant examples of this architecture is the Church of Santa Maria d'Arties. The large movements of the masonry have deformed the structure to the limit, challenging the principles of stability. These large deformations have already been warned, described and studied by several authors as Bassegoda i Nonell [3], Villanueva [4], Saez [5] and Polo and Cots [6].

This construction and Val d'Aran landscape should be saved through the international documents about heritage conservation as the Nara document on authenticity of 1994 [7], Carta del patrimonio vernáculo construido (1999), ratified by the 12th General Assembly of ICOMOS in Mexico [8], and the values to analysis, conservation, and restoration of structures from Architectonic Heritage of 14th General Assembly of ICOMOS, in Victoria Falls, Zimbabwe [9] - all framed within the European Landscape convention, Florence, October 20, 2000 [10].

The interest of Romanic structures made us, the Escola Técnica Superior de Arquitectura of URV, study them during the 2012-13 and 2013-14 courses. Three campaigns have been made during this period. The first church studied, in winter 2012, was Santa María de Arties, where Basegoda (1972) first noticed the big deformations.

In the second campaign, in spring 2013, Santa Maria d'Arties was studied in more detail. The two campaigns helped us get a perspective of the conditions of Romanic buildings of Vall D'Aran.

In the third campaign, the churches studied were Vilamós, Salardú, Bossost and Unha.

In these three campaigns, a layout of the floor plan and sections of named churches were made. The main characteristics are: the churches have a basilica plan with three naves, two laterals with similar height and one higher central nave. All the churches, except the Vilamos one, have a Romanic apse and all the churches have a bell tower. Finally, the most important characteristic is that all the churches have a central barrel vault and half barrel vault at the lateral naves.

The Church of Santa Maria d'Arties can be defined as a rectangular space of about $19.60 \times 13.8 \mathrm{~m}$ to the apsidioles (Figure 1). This measure is only an approach, as the great deformations make impossible to accurately set the 
general building measures. The construction is raised in the typical East-West orientation, with a central nave and two collaterals, each with four bays with a span of about $5 \mathrm{~m}$. The central pillars support the arc formerets under the barrel vault and the lateral half-vaults. In the western side of the church it is found also a wooden choir over the bay of access. The heading is currently finished with a semicircular apse, reconstructed during last years, and the two original apsidioles. All of them are covered with hemispherical domes. The naves present a typical deformation pattern according to the structural arrangement. Vertical supporting elements, especially the pillars, have moved because of the thrusts of vaults.
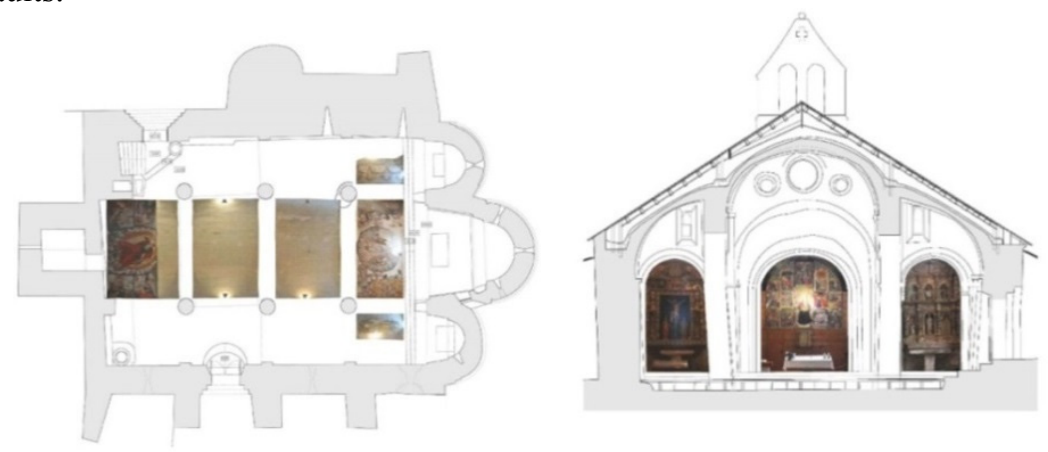

Figure 1: Plan and section of Santa Maria d'Arties [11].

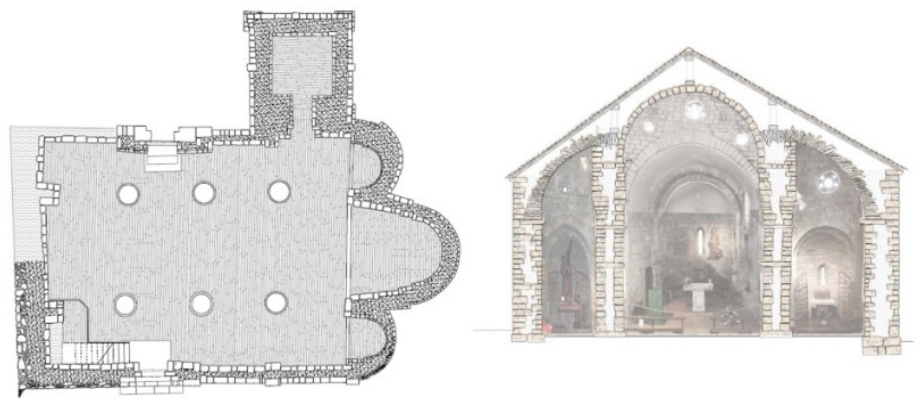

Figure 2: Plan and section of Mair de Diu dera Purificacion of Bossost [12].

The Church of Mair de Diu dera Purificacion of Bossost (Figure 2) is characterized by being all built according to 12 th century style. It has a basilical plan with three apses. The tower belt is in the north-east facade and the construction is rotated 15 grades of east-west orientation. The inner space can be defined as a rectangular of about $19.86 \times 10.97 \mathrm{~m}$. The church has six circular columns of freestone. 
The Church of Santa Eulària d'Unha (Figure 3) has a basilical plan with three naves. The apse has a Lombard style. In the north-east, it has a tower bell from the 18th century. The construction is raised with the typical east-west orientation and the interior dimensions are $21.27 \times 10.92 \mathrm{~m}$.
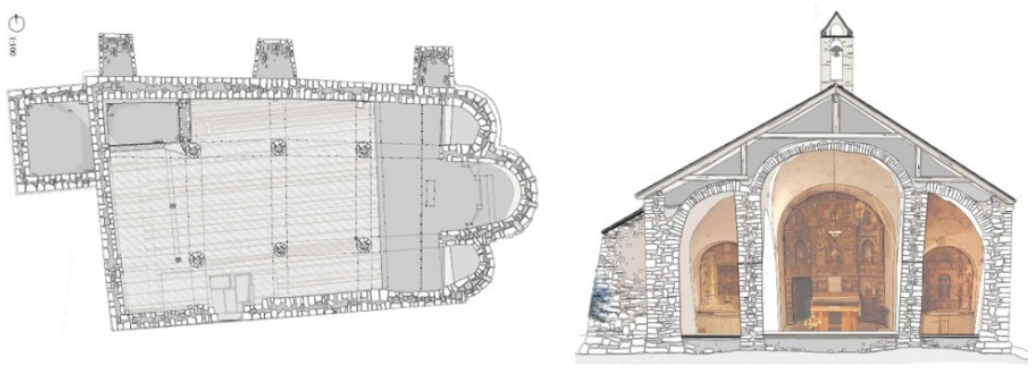

Figure 3: Plan and section of Santa Eulària d'Unha [13].
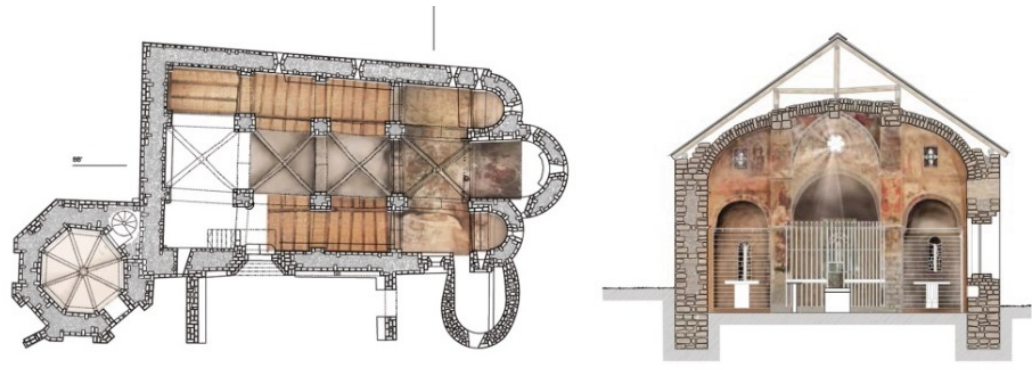

Figure 4: Plan and section of Sant Andrèu of Salardú [14].

The Church of Sant Andrèu of Salardú (Figure 4) belongs to late Romanic (XIII century). The construction is raised with an east-west orientation. The interior dimensions are $24.27 \times 11.76 \mathrm{~m}$. In the south-east angle there is a tower belt from the XV century with octagonal ground plan and Gothic vault. Inside it has a Gothic style, covered with ribbed vault over cruciform columns.

The Church of Santa María de Vilamós (Figure 5) has a central nave and one of laterals naves with a barrel vault, but the other one is a half barrel vault. The vaults are over four circular and two cruciform columns. The Romanic tower bell is in the south-east facade and the construction is rotated 15 grades of east-west orientation. The inner space can be defined as a rectangular space of about $24.09 \times 9.85 \mathrm{~m}$.

The traditional elastic theory is based on resistance, stiffness and stability [16]. The concept of stability rules masonry constructions, thus, historical buildings as the churches of Val d'Aran are ruled by this criteria. These structures shall be assessed considering the overall stability, which sometimes is due to its capacity to assume geometrical deformations.

The theoretical framework for the assessment of masonry structures is currently well developed, according to the principles of limit analysis defined by 

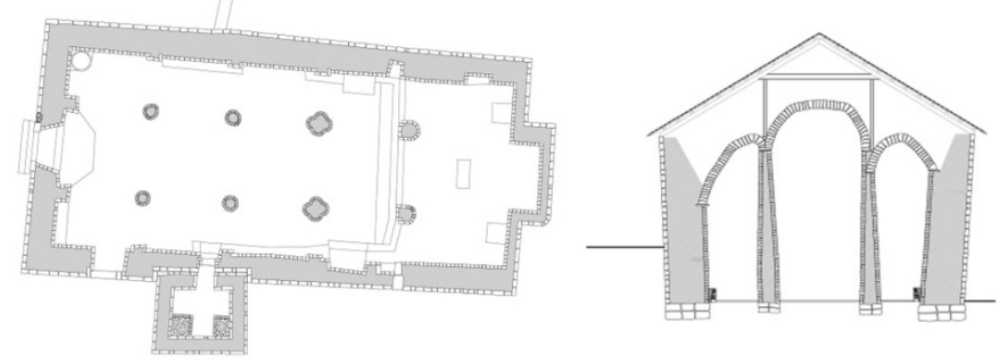

Figure 5: Plan and section of Santa María de Vilamós [15].

Heyman [17] and developed by many authors, like Huerta [18] and Block et al. [19]. Those structures are subjected to compression, being far from its mechanical limits, even in the largest buildings. So, they are considered to have infinite resistance to compression. Also, the tensile strength is considered to be null and the friction prevents sliding between pieces.

\section{Objective}

The paper sets out the study of the constructive evolution in the churches and the quantification of the geometric deformation in relation with the constructive system of vault used.

The study will be done with the constructive sections of the elevations done in the different churches during the 2011-2014 campaign, from which the admissible mathematic strain deformation will be studied.

This research goes a step further, focusing on the equilibrium conditions of the structure from an analytical point of view. The understanding of the initial conditions will shed some light on the origin of the movements, as well as the assessment of the current geometry.

\section{Method}

The transversal section has a bigger deformation. It is due to the fact that the nave is a feebler element; the edge walls receive the weight of vaults. The transversal section is composed by: a central vault supported by two columns, and two edge vaults supported by a wall and a column.

In Roman tradition, the columns are distributed through visual patterns. The units are distributed through cross-axial pair. Schemes which employ cross-axial pairs were used in Rome from the fourth to the seventh centuries, and again during the twelfth and thirteenth centuries. In these two periods, however, there is a significant difference in the way the pairs of columns were arranged.

In Early Christian times, the elements were commonly disposed in hierarchical patterns which placed the finest or rarest shafts and capitals closest to the apse, while those of lesser value were relegated to the facade end of the 


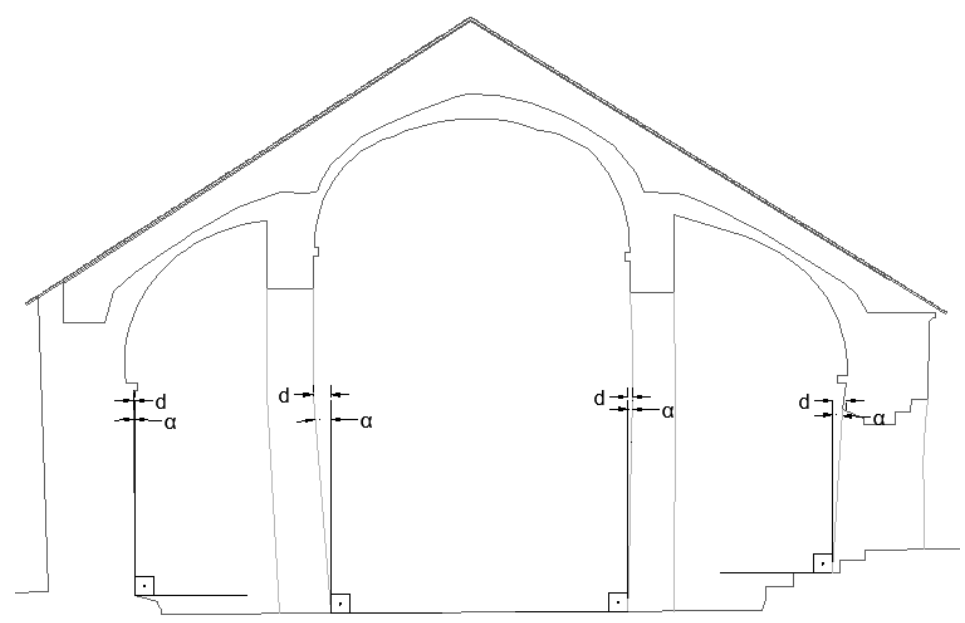

Figure 6: Typology of section study.

colonnades. In high medieval churches, the rare or unusual elements were not necessarily placed near the apse [20]. For this reason, when studding a deformation perpendicular to this axis, the section chosen is an indifferent one between two columns. For this study, we choose the section with more horizontal slopes.

The wall deformation is related with its composition, the amount of stone and mortar is important. The evolution of stereotomy has an inflexion point in 1020 1030 years, when the builders researched the plasticity of walls [21]. Vergnolle observed a standardization of stones from 1020 to 1030 years. The stone was longer with a better stereotomy and there is little mortar. The mortar board passes from $7-8 \mathrm{~cm}$ to $3-4 \mathrm{~cm}$.

For this study, it is necessary to measure the vertical wall and columns deformation. The vault has a height, and it is transmitted to the wall. The vault and wall must work jointly to transmit the weigh. The inclination of weight vector is function of vault. The thrust of pointed arch is more vertical than a segmental vault.

The vault may deform due to the leaning of buttresses. The structure is deformed as a three-hinged arch and failure occurs when a fourth hinge is created on the bottom right at the base of the buttress. The expected measure is to reach a maximum lean of $3.0^{\circ}$ before collapse, though if buttress fracturing is taken in account, the lean is $2.5^{\circ}$ [22].

In the end of the study, a deformation and vault typology will be compared.

\section{Calculation of vault typology}

The vaults of Vall d'Aran churches are very deformed, but for being able to calculate the original form it is necessary to make the assumption that the length of original vault and the length of deformed vault are the same. In an ideal 
situation, where the vault is an arch of circumference with a diameter of $1 \mathrm{~m}$, the fraction of arch length and diameter is equal to $1.57 \mathrm{~m}$. We calculated the relation between the arch of all the churches and the non-deformed width of vaults and compared it with the ideal situation. The result can be: if relation of arch is higher than 1.57 the arch is pointed; if relation of arch is similar to 1.57 , the arch is a barrel vault; and if the relation is lower than 1.57 the arch is a segmental arch.

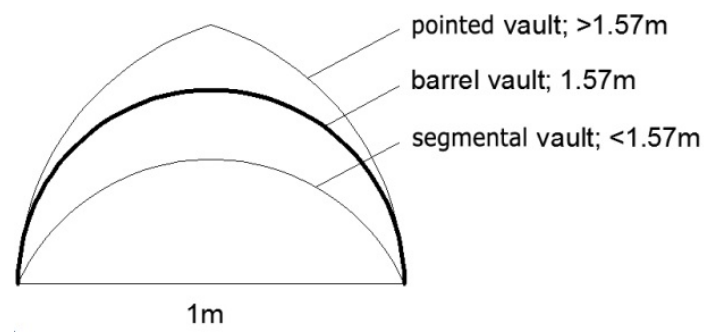

Figure 7: Vault length study.

Table 1: Vault study.

\begin{tabular}{|l|c|c|c|c|c|}
\cline { 2 - 6 } \multicolumn{1}{c|}{} & Vilamós & Bossost & Salardú & Unha & Arties \\
\hline Vault length & 5.27 & 7.55 & 7.05 & 6.27 & 9.25 \\
\hline Vault width & 3.02 & 4.59 & 3.59 & 4.56 & 5.96 \\
\hline Relation & $\mathbf{1 . 7 4}$ & $\mathbf{1 . 6 4}$ & $\mathbf{1 . 9 6}$ & $\mathbf{1 . 3 7 5}$ & $\mathbf{1 . 5 5}$ \\
\hline
\end{tabular}

Another system for studying the vault typology comes from the relation between radius and depth: if the church has a barrel vault, the radius is similar to vault depth. If the church has a segmented vault the radius is higher than the depth and if the church has a pointed vault the radius is less than the depth.
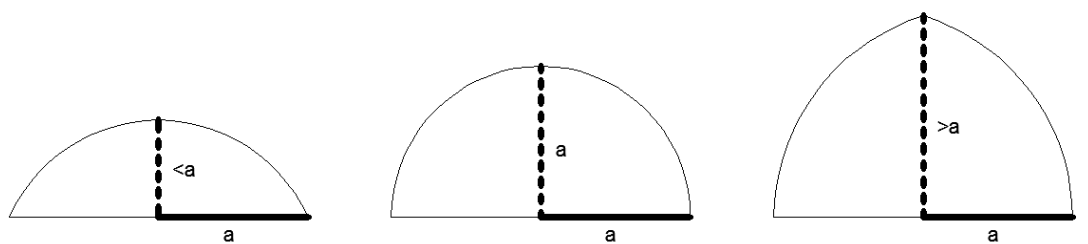

Figure 8: Vault depth study.

Table 2: Vault depth study.

\begin{tabular}{|l|c|c|c|c|c|}
\cline { 2 - 6 } \multicolumn{1}{c|}{} & Vilamós & Bossost & Salardú & Unha & Arties \\
\hline Radius measured (a) & 1.67 & 2.40 & 2.24 & 1.99 & 2.94 \\
\hline Depth & 1.51 & 2.295 & 1.795 & 2.28 & 2.98 \\
\hline
\end{tabular}


From this study we can be assured that only the Arties Church has a barrel vault. The Church of Unha has a segmental vault and the Churches of Vilamós, Bossost and Salardú have a pointed vault.

In the Vilamós Church, the relation between the distance among columns and the width of pillars is 5 . This relation has not a pattern in the other churches.

\section{Deformation study}

Most of the buildings show deformations in the columns and walls. Other important data is the asymmetry of the deformations. The deformation has been measured in degrees $(\alpha)$ in the wall or column base. Another measure taken is the horizontal movement in the basis of $\operatorname{arch}(d)$.

Vilamos has two degrees of deformation in the north vault, one and three in the inner columns and two degrees in the south wall. Unha has two degrees in the north vault, four and three in the inner columns and four degrees in the south wall. Arties has cero degrees in the north vault, one and five in the inner columns and four degrees in the south wall. Therefor the vaults have absorbed part of the deformation. Bossost and Salardú have no inclination (table 3). The Vilamós Church has a horizontal deformation of $11 \mathrm{~cm}$ with a width wall of $1.66 \mathrm{~m}$. Unha has a deformation of $9 \mathrm{~cm}$ with wall of $1.13 \mathrm{~m}$ width and Arties has a $3 \mathrm{~cm}$ deformation with a $0.98 \mathrm{~m}$ width.

Table 3: Deformation study.

\begin{tabular}{|l|c|c|c|c|c|}
\cline { 2 - 6 } \multicolumn{1}{c|}{} & Vilamós & Bossost & Salardú & Unha & Arties \\
\hline$\alpha$ north wall & 2 & 0 & 0 & 2 & 0 \\
\hline d north wall & 0.11 & 0 & 0 & 0.09 & 0.029 \\
\hline$\alpha$ north inner column & 1 & 0 & 0 & 4 & 1 \\
\hline d north inner column & 0.03 & 0 & 0 & 0.098 & 0.32 \\
\hline$\alpha$ south inner column & 3 & 0 & 0 & 3 & 5 \\
\hline d south inner column & 0.09 & 0 & 0 & 0.2 & 0.09 \\
\hline$\alpha$ south wall & 2 & 0 & 0 & 4 & 4 \\
\hline d south wall & 0.34 & 0 & 0 & 0.11 & 0.21 \\
\hline
\end{tabular}

The cylindrical column was adopted from the $10^{\text {th }}$ century and it was used firstly in buildings with wood truss. The masonry pillars were from the $12^{\text {th }}$ century [23]. The proportions of these cylindrical cells appear to depend only on the charge that they support. The walls are of masonry. The results of comparing the degrees with the horizontal movement show that an inclined wall has sagged. This shows us that the north wall, south wall and inner columns have a different inclination.

The response to deformation in Vall d'Aràn churches has been to install buttresses. It is what happens in Arties, Unha and Salardú. Arties in particular, has a higher strain and due to that, it has $51 \mathrm{~m}^{2}$ of buttress area. Unha has a $12.26 \mathrm{~m}^{2}$ buttress area, with a $0.11 \mathrm{~m}$ strain. 

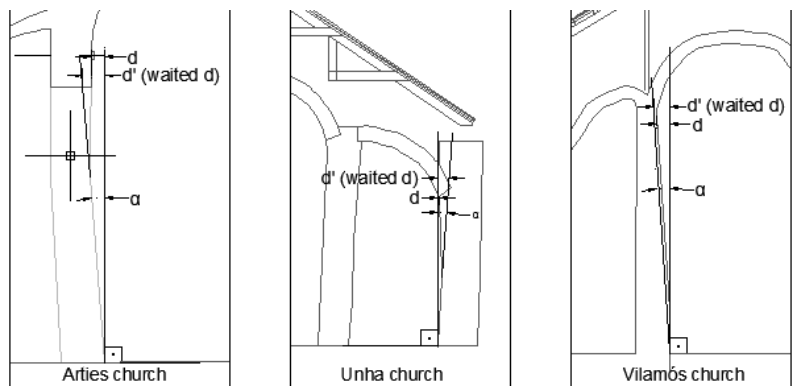

Figure 9: Deformation study.

\section{Relation between vault and wall deformation}

When comparing the typology of the vaults and the deformation of the walls, the result shows us that the deformation is related with the typology of vault.

Table 4: Width wall-reformation study.

\begin{tabular}{|c|c|c|c|}
\hline & Vault typology & Max. def. (d) & Width wall \\
\hline Arties & Barrel vault & 0.32 & 1.60 \\
\hline Unha & Downloaded vault & 0.11 & 0.88 \\
\hline Bossost & Apunted vault & 0 & 1.15 \\
\hline Salardú & Apunted vault & 0 & 1.40 \\
\hline Vilamós & Apunted vault & 0.34 & 1.62 \\
\hline
\end{tabular}

This explains to us that the relation between width walls and deformation is proportional (table 4). If high vault difference is compared with width of walls and deformation walls, they have an inverse proportional relation. So, the deformation depends on the edge vaults too (Figure 10). If the church has a high height vault difference, there is a lower deformation and if there is a low height vault, there is more deformation.

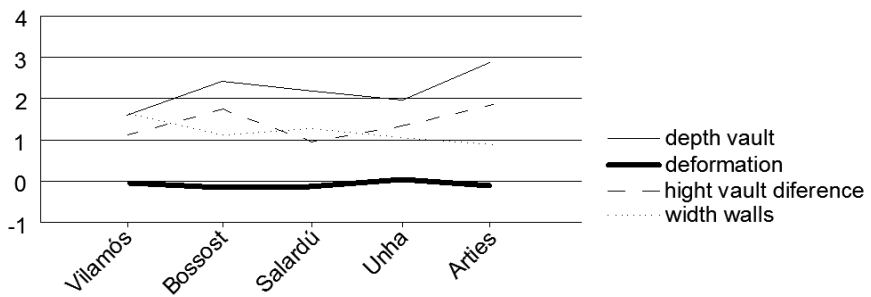

Figure 10: Vault study. 
In this study, the church with more difference between the key of vault is Arties, with $1.91 \mathrm{~m}$. It has a maximum deformation of $0.21 \mathrm{~m}$. The second church with more deformation is Unha, it has a $1.45 \mathrm{~m}$ of difference between edge vault and central vault and has a $0.11 \mathrm{~m}$ of strain. And the Church of Vilamós shows a peculiarity: it has a vault difference of $1.25 \mathrm{~m}$ between central vault and edge vaults, but the left one is a quarter vault and it has a $0.11 \mathrm{~m}$ strain and the right vault is a barrel vault and it has a $0.34 \mathrm{~m}$ strain.

The proportion of inner space is compared with the deformation too, so, to do this study a proportion of three spaces of the transversal section has been measured and compared with the maximum deformation of this space (table 5).

We compared a number of edge vaults with the maximum deformation of its. They show a proportional relation: when the proportions up the deformation up too.

Table 5: $\quad$ Study of deformation - church proportion.

\begin{tabular}{|l|l|l|l|l|l|l|}
\hline Edge space & Vila. (l) & Unha. (1) & Arties (l) & Vila. (r.) & Unha (r.) & Arties (r.) \\
\hline proportion & 3.2 & 2.4 & 2.7 & 4 & 2.3 & 2.5 \\
\hline deformation & 0.11 & 0.09 & 0.32 & 0.34 & 0.2 & 0.21 \\
\hline
\end{tabular}

(1.: left edge space; r.: right edge space.)

The proportion and deformation of central vault is not related with the other data because it does not have the same characteristics. The edge vaults send the strength in one direction, while the central vault sends the strength in two opposite directions.

The height and width of church have been compared with the maximum deformation. There we can see that the relation between the width of church and the horizontal movement is proportional. The Church of Vilamós has a height of $6.08 \mathrm{~m}$ and $9.62 \mathrm{~m}$ width with an $11 \mathrm{~cm}$ deformation. The Church of Unha has a height of $6.66 \mathrm{~m}$ and $10.21 \mathrm{~m}$ width with a $20 \mathrm{~cm}$ deformation and Arties has a height of $9.76 \mathrm{~m}$ and $13.86 \mathrm{~m}$ width with a $32 \mathrm{~cm}$ deformation (table 6).

Table 6: Study of dimensions - church proportion.

\begin{tabular}{|l|l|l|l|l|l|}
\cline { 2 - 6 } \multicolumn{1}{c|}{} & Vilamós & Bossost & Salardú & Unha & Arties \\
\hline Nave height & 6.08 & 8.55 & 9.09 & 6.66 & 9.76 \\
\hline Nave width & 9.62 & 10.82 & 11.18 & 10.21 & 13.86 \\
\hline Deformation & 0.11 & 0 & 0 & 0.20 & 0.32 \\
\hline
\end{tabular}

\section{Conclusions and future work}

This study shows that the vaults of church studied are not only barrel ones, in fact, the Arties Church is the only that has a barrel vault. The Church of Unha has a segmental vault and the Churches of Vilamós, Bossost and Salardú have pointed vaults. This fact is important for understanding the Romanesque construction (wall, columns). 
This study shows that the typology of vault is important for the deformation of walls and inclination of columns. An important data is the difference of measures between the height of the central and edge vaults. It has an inverse proportion. If the church has a high height vault difference there is a lower deformation, and if there is a low height vault there is more deformation. The typology of edge vault affect mainly to the wall's edge. The column between vaults has equilibrium of efforts. The transversal section of Vilamos Church has a central barrel vault, a middle barrel vault with a $0.11 \mathrm{~m}$ of strain in the left space, and in the right it has a barrel vault with $0.34 \mathrm{~m}$ of strain.

If we focused the study only in the relation between the church proportion and its deformation, we would make the mistake to think that the proportion of central nave is not important to the strain, but it is, so the general proportion has tis interest too. Vilamós has a higher proportion, 0.875 ( $7 \mathrm{~m}$ height $\mathrm{x} 8 \mathrm{~m}$ width) and $0.34 \mathrm{~m}$ strain; the Church of Arties has a 0.7 of proportion and $0.32 \mathrm{~m}$ strain; and the Church of Unha has a proportion of 0.625 and a $0.2 \mathrm{~m}$ maxima strain. We can affirm that the proportion has a proportional relation with the strain.

For the strain, it is important to know the quality and quantity of masonry. The church with a higher percentage of built walls in relation with the floor area is Vilamos $(32.43 \%$ ) with a $0.34 \mathrm{~m}$ strain; the Church of Arties has a $30.69 \%$ with a $0.21 \mathrm{~m}$ strain; and the Church of Unha has a $24.95 \%$ of built walls and it has a $0.11 \mathrm{~m}$ strain. So the wall volume has a proportional relation with the strain.

The current work is based in bi-dimensional documentation. This data is correct for a first approximation to Romanesque. But this first part leads us to working in a more detailed data collection. Actually, we have started taking data of the churches through scan laser. This new information allows us to have clouds of points from all buildings and, for example, to make consecutive sections.

The laser scanner used is a C20 Leica, a compact device for mid-range measurements which uses the time-of-flight principle, with a complete field of view $\left(360^{\circ}\right.$ horizontal, $270^{\circ}$ vertical $)$ and an accuracy of $6 \mathrm{~mm}$ per point up to a range of $50 \mathrm{~m}$. Images are captured at each station in order to specify the colour of the points.

Finally, it is not only necessary to go deeper in the study of the mentioned buildings. The Vall d'Aràn has almost 20 Romanesque churches in its boundaries with interest to our study; our intention is to study each of them. The reason why we have chosen the first ones for the study lies in their similar vaults.

\section{Acknowledgements}

The authors would like to acknowledge Bisbat d'Urgell and Conselh Generau d'Aran, for kindly opening the door of their churches to our research on architectural heritage. 


\section{References}

[1] Puig i Cadafalch, J., "Les iglesies romàniques ab cobertes de fusta de les Valls De Bohí y d'Aran," Anu. l'Institut d'Estudis Catalans, vol. MCMVII, pp. 119-136, 1908.

[2] Bassegoda i Nonell, J., "Estética expresionista de la arquitectura románica lombarda en Catalunya como consecuencia de las deformaciones formales y estructurales de las iglesias," Re Restaur., vol. 2, p. 51, 1974.

[3] Bassegoda i Nonell, J., "La Iglesia de Santa María de Arties, barroca y racionalista. Un templo sin cimientos," La Vanguardia Española, no.28, septiembre, p. 51, 1972.

[4] Villanueva, "Las bóvedas de cañon," Re Restaur., vol. 2, pp. 145-158, 1974.

[5] Saez, "Primera fase del proyecto de restauración de la Iglesia de Santa María de Artíes en el Valle de Arán (Lérida)," Cuad. Arquit. Urban, no. 116, pp. 63-71, 1976.

[6] Polo and Cots, "Santa Maria d'Arties (Naut Aran, Val d'Aran): Un exemple integrau a nivèu de restauracion d'un monument a compdar des entresenhes arqueologiques," in Cicle de conferències patrimoni arqueològic i arquitectònic a les Terres de Lleida, pp. 75-103, 2009.

[7] "Documento de Nara en Autenticidad," in Conferencia de Nara, 1994.

[8] Asamblea General ICOMOS, Lugar - Memoria - Significado: Preservar los valores inmateriales de los monumentos y sitios, 2003.

[9] Asamblea General ICOMOS, El uso racional del Patrimonio - Patrimonio y Desarrollo, 1999.

[10] Convenio europeo del paisaje. Florencia, Italy, 2000.

[11] Cartanyà M., Escarrè, A., Jacas, T., Martí, J., Padró, X., and Rodriguez, D., "Santa María d'Arties." Reus, 2012.

[12] Arnao R. and Soler, C., "Mair de Diu dera Purificacion of Bossost." Reus, 2013.

[13] Fabregat, J. and Royo, A., "Santa Eulària d'Unha." Reus, 2013.

[14] Gonzalvo, C., Olucha, C., and Vallés, J., "Sant Andrèu de Salardú." Reus, 2013.

[15] Marín, C., Roset, A., and Weber, J., "Santa María de Vilamós." Reus, 2013.

[16] Aroca, "Introducción a la Elasticidad." Cuad. del Inst. Juan Herra, vol. 1, $16-11,2001$.

[17] Heyman, J., The stone skeleton: structural engineering of masonry architecture. Cambridge, 1995.

[18] Huerta, S., "Mechanics of masonry vaults: the equilibrium approach," in Proc. of the $1^{\text {st }}$ Int. Cong. on Structural Analysis of Historical constructions, Guimaraes, pp. 47-70, 2001.

[19] Block, P., De Jong, M., and Ochsendorf, J., "As Hangs the Flexible Line: Equilibrium of Masonry Arches," Nexus Netw. J., vol. 8, no. 2, pp. 38-47, 2006. 
[20] Malmstrom R.E., "On behalf of the neurosciences," Behav. Brain Sci., vol. 1, no. 2, p. 113, 1978.

[21] Vergnolle, É., "La pierre de taille dans 1 ' architecture religieuse de la première moitié du XIe siècle," pp. 229-234, 1996.

[22] Block, P., Ciblac, T., and Ochsendorf, J., "Real-time limit analysis of vaulted masonry buildings," Comput. Struct., vol. 84, pp. 1841-1852, 2006.

[23] Vergnolle, É., "La colonne à l'époque romane. Réminiscences et nouveautés," pp. 141-174, 1998. 